\title{
The palaeolimnological potential of diatom assemblages in floodplain lakes of the Danube Delta, Romania: a pilot study
}

\author{
Holger Cremer ${ }^{1}$, Anthonie D. Buijse ${ }^{2}$, André F. Lotter ${ }^{1}$, Willem Oosterberg ${ }^{2}$ \& Mircea Staras ${ }^{3}$ \\ ${ }^{1}$ Universiteit Utrecht, Department of Geobiology, Laboratory of Palaeobotany and Palynology, Budapestlaan 4, \\ 3584 CD Utrecht, The Netherlands \\ ${ }^{2}$ Institute for Inland Water Management and Waste Water Treatment RIZA, P.O. Box 17, 8200 AA Lelystad, \\ The Netherlands \\ ${ }^{3}$ Danube Delta National Institute DDNI, 165 Babadag Street, 8800 Tulcea, Romania
}

Received 11 March 2003; in revised form 5 May 2003; accepted 20 May 2003

Key words: diatoms, shallow lakes, sediments, floodplain, Danube Delta, Romania

\begin{abstract}
Within the framework of a palaeolimnological pilot study, the potential of sedimentary diatom assemblages for the reconstruction of the eutrophication history was studied in short sediment cores from five shallow lakes located in the Romanian Danube Delta. A total of 234 diatom taxa representing 57 genera could be identified but diatom assemblages are generally predominated by a few species only. Loss on ignition percentages, total diatom abundances and diatom downcore successions largely vary within the single sediment cores and between all five lakes. This suggests the presence of various lake environments within the Danube Delta, each characterized by lakespecific geomorphological, sedimentological, hydrological, and biological conditions. Highly variable depositional conditions are also confirmed by radiocesium measurements in two of the five cores suggesting distinct inter-lake differences in the sedimentation rate. Causes for the great intra-lake and inter-lake variability in diatom downcore successions are difficult to specify and may include changes in the physico-chemical conditions, aquatic vegetation cover, water depth, river influence, turbidity and inter-biotic interactions. However, based on this pilot study, it is likely that the spatial and temporal distribution of sedimentary diatom assemblages in Danube Delta lakes were not triggered by the trophic state. The delta lakes likely became meso- to eutrophic long before 1950, possibly during late-Holocene times.
\end{abstract}

\section{Introduction}

Shallow lakes in floodplains of large rivers display a great variety of different habitats and ecological gradients. One of the largest floodlains in Europe, enclosing hundreds of shallow lakes, is the Danube Delta (Fig. 1). Hydrological characteristics in the delta lakes largely fluctuate caused by seasonal and interannual variability of river and lake water fluxes due to water transport via channels, periodical floodings, and water flow under reed beds (Coops et al., 1999; Buijse et al., 2002). The spatial and temporal variability of hydrological conditions in the floodplain lakes also leads to distinct differences in the plant, fish, zooplankton and phytoplankton communities (Coops et al., 1999; Oosterberg et al., 2000; Nãvodaru et al., 2002).

The Danube Delta drains the $2860 \mathrm{~km}$ long Danube River which has its origin near the German village Donaueschingen in the Black Forest and passes eight countries on its way to the Black Sea (Fig. 1). The catchment area of the Danube River is approximately $817000 \mathrm{~km}^{2}$ and the delta itself has a surface area of ca. $5800 \mathrm{~km}^{2}$ (Oosterberg et al., 2000). Although the Danube Delta recently still displays a natural gradient of habitats with characteristic floras and faunas, man-made stress factors like eutrophication and geomorphological impacts became evident since the early 1970's due to dike and channel construction, fish farming, reed harvesting and agricultural activities within 

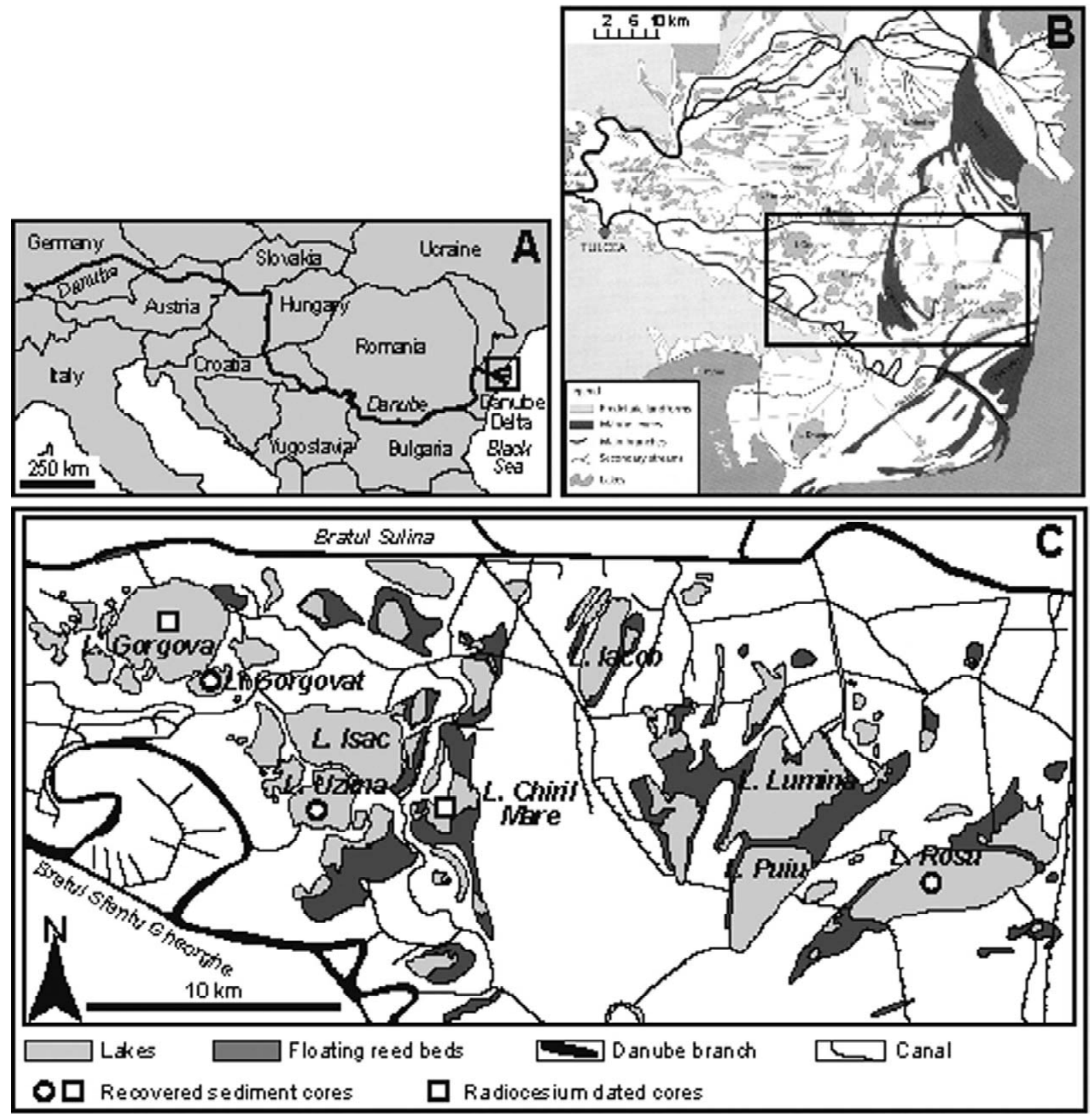

Figure 1. Geographical maps of the study area. (A). The Danube River from the origin to its delta. (B). Morphography of the Danube Delta (taken from Oosterberg et al., 2000). (C). Sampling sites in the Gorgova-Isac and Roşu-Puiu lake complexes.

the delta, and due to contaminated Danube River water influx (Heliotis et al., 1994; Schmidt, 2001).

The present paper summarizes a pilot study on the potential of sedimentary diatom assemblages as an indicator for trophic state changes in Danube Delta lakes during the past 50-100 years. This is the first palaeolimnological study of Danube Delta lakes and questions to be evaluated include (1) the composi- tion and succession of diatom assemblages in five short sediment cores, (2) the time presumably represented by five short sediment cores, and (3) possible palaeoenvironmental implications of the diatom successions.

Diatoms or Bacillariophyceae are since long time used in bioassessments and historical reconstructions as indicators for modern and past changes of ecolo- 
Table 1. Core site description in lakes in the Danube Delta. The cores have been analyzed for the diatom succession $(*)$, the loss on ignition percentages $\left({ }^{\circ}\right)$, and the radiocesium concentration (\#)

\begin{tabular}{|c|c|c|c|c|}
\hline $\begin{array}{l}\text { Sampling } \\
\text { date }\end{array}$ & Location & $\begin{array}{l}\text { Water } \\
\text { depth }[\mathrm{m}]\end{array}$ & $\begin{array}{l}\text { GPS Position } \\
\text { [UTM] }\end{array}$ & $\begin{array}{l}\text { Core length } \\
{[\mathrm{cm}]}\end{array}$ \\
\hline \multirow[t]{2}{*}{6 June 2002} & Core DD4 * \# & 1.60 & 35 T 0682906 & 38 \\
\hline & Lake Chiril Mare & & UTM 4995240 & \\
\hline \multirow[t]{2}{*}{6 June 2002} & Core DD5*。 & 1.50 & 35 T 0678010 & 36 \\
\hline & Lake Uzlina & & UTM 4995393 & \\
\hline \multirow[t]{2}{*}{8 June 2002} & Core DD6*。 & 3.00 & 35 T 0700836 & 46 \\
\hline & Lake Roşu & & UTM 4991644 & \\
\hline \multirow[t]{2}{*}{9 June 2002} & Core DD7 \# & 2.40 & 35 T 0672171 & 52 \\
\hline & Lake Gorgova & & UTM 5001871 & \\
\hline \multirow[t]{2}{*}{9 June 2002} & Core DD8*。 & 2.40 & 35 T 0672221 & 46 \\
\hline & Lake Gorgova & & UTM 5001761 & \\
\hline \multirow[t]{2}{*}{9 June 2002} & Core DD9*。 & 1.20 & 35 T 0673166 & 48 \\
\hline & Lake Gorgovaţ & & UTM 5000145 & \\
\hline
\end{tabular}

gical conditions (Stoermer \& Smol, 1999). However, our knowledge about diatom assemblages and their palaeolimnological potential in river delta lakes is relatively little. One of the few comprehensive palaeostudies on delta lake diatoms is available from the Mackenzie Delta in Arctic Canada (Hay et al., 2000; Michelutti et al., 2001), which, compared to our study, is based on a much bigger database. Hay et al. (2000) and Michelutti et al. (2001) could show that lake diatom assemblages in the Mackenzie Delta are good indicators for past changes in macrophyte production and river influence.

Also, the knowledge about the diatom flora in lakes of the Danube Delta is rather poor. Whereas there are a relatively good qualitative and quantitative data on modern planktic diatoms (Török, 1998; Tudor \& Török, 1999; Ibelings et al., 2000), benthic and epiphytic diatom communities as well as fossil diatom sediment assemblages of the delta lakes are insufficiently studied. Most available literature on non-planktic diatoms is relatively old and, moreover, usually restricted to a description of the identified species (e.g. Moruzi et al., 1960; Moruzi, 1968 and references therein).

\section{Study area}

The lakes investigated for this study are located in the Romanian Danube Delta Biosphere Reserve (DDBR) between the Sulina river branch in the north and the Sfantu Gheorghe river branch in the south (Fig. 1). Sediment cores were taken in five shallow lakes: L.
Gorgova, L. Gorgovaţ, L. Uzlina, L. Chiril Mare, and L. Roşu (Table 1). The selected lakes represent an east-west transect within the Danube Delta and are partly also subject to long-term limnological monitoring (Oosterberg et al., 2000). Water depths are between 1.20 and 3.00 metres and the recovered cores have lenghts between 36 and $52 \mathrm{~cm}$. The current limnology of the lakes is determined by the seasonal variabilty of Danube river water discharge. The large network of canals and channels within the Danube Delta supports a quasi-canalization of the water flow from the delta entrance towards the Black Sea. As a result of the seasonal fluctuations of river water fluxes, Danube Delta lakes show a large variability in the light, nutrient and turbidity conditions, and in the occurrence of aquatic vegetation (Coops et al., 1999; Oosterberg et al., 2000). Although lake classification within floodplains is generally difficult, Buijse et al. (2002) defined three types of Danube Delta lakes (Table 2) based on differences in trophic state, topography, vegetation, and zooplankton and fish communities. Based on this classification (Table 2), L. Gorgova and L. Roşu represent type 1-lakes, L. Uzlina is a type 2-lake, and L. Gorgovat and L. Chiril Mare are assigned as type 3-lakes.

\section{Materials and methods}

\section{Sediment sampling}

Lake sediment coring was carried out in June 2002 during a houseboat-based field campaign. A gravity corer (UWITEC Corp., Austria) equipped with PVC tubes (diameter: $6 \mathrm{~cm}$ ) was used to recover six short sediment cores (Table 1). Five of the six cores were opened longitudinally shortly after recovery onboard the houseboat (the sediment was stiff enough to apply this method), one core was kept for radionuclide measurements. Following lithological description and photographical documentation which revealed only minor stratigraphical disturbances within the entire core sections, one core half was sampled at $1 \mathrm{~cm}$ intervals for diatom analysis, the other core half was sampled in $2 \mathrm{~cm}$ intervals for physical and geochemical analyses. The intact core and all subsamples were stored in a dark cool place on the houseboat until further investigation. 
Table 2. Typology of Danube Delta lakes. 'Low', 'intermediate' and 'high' refer to relative values (after Buijse et al., 2002, modified)

\begin{tabular}{|c|c|c|c|}
\hline Parameter & $\begin{array}{l}\text { Type } 1 \\
\text { L. Gorgova, Roşu }\end{array}$ & $\begin{array}{l}\text { Type } 2 \\
\text { L. Uzlina }\end{array}$ & $\begin{array}{l}\text { Type } 3 \\
\text { L. Chiril Mare, Gorgovat }\end{array}$ \\
\hline Size & Large & Intermediate & Small \\
\hline Water depth & Deep & Shallow & Shallow \\
\hline Substratum & Sand-silt & Clay & Organic \\
\hline Dominant fish & $\begin{array}{l}\text { Indifferent and still-water } \\
\text { species }\end{array}$ & $\begin{array}{l}\text { Species indifferent to low } \\
\text { velocities }\end{array}$ & Still-water species \\
\hline Zooplankton abundance & High & Low & Low \\
\hline $\begin{array}{l}\text { Phytoplankton and } \\
\text { cyanobacteria } \\
\text { abundance }\end{array}$ & High & Low & Low \\
\hline Macrophyte abundance & Low & High & High \\
\hline $\begin{array}{l}\text { Dominant macrophyte } \\
\text { species }\end{array}$ & None & Potamogeton trichoides & Nitellopsis obtusa \\
\hline Area of reed belt & Varying & Small & Large \\
\hline $\begin{array}{l}\text { Phosphorus } \\
\text { concentration }\end{array}$ & Low & Low & High \\
\hline Nitrogen concentration & High & High & Low \\
\hline Turbidity & Turbid & Clear & Clear \\
\hline
\end{tabular}

\section{Sedimentation rates and radiocesium measurements}

Measurements of cesium radionuclid activities $\left({ }^{137} \mathrm{Cs}\right)$ were carried out on two sediment cores in order to obtain estimates of sedimentation rates and to establish a depth-age relationship. Single measurements of the ${ }^{137} \mathrm{Cs}$ activity in freeze-dried, $2 \mathrm{~cm}$ thick sediment subsamples from core DD4 recovered in L. Chiril Mare were carried out at the Institute for Inland Water Management and Wastewater Treatment (RIZA) using a High Purity Germanium detector. A second core, core DD7 from L. Gorgova, was analysed on radiocesium activity using the non-destructive, entire-core PHAROS technique at the Nuclear Geophysics Division of the Kernfysisch Versneller Instituut (KVI) at Groningen University. This technique measures entire sediment cores in $2 \mathrm{~cm}$ intervals using Bismut-Germanium-Oxide $\left(\mathrm{Bi}_{4} \mathrm{Ge}_{3} \mathrm{O}_{12}\right)$ detectors (see http://ngd.kvi.nl/sediment/pharos for further information).

\section{Loss on ignition (LOI) measurements}

LOI measurements were carried out on subsamples of four sediment cores in order to obtain an estimation of the organic carbon and carbonate contents. For this purpose, between 1.5 and $5.0 \mathrm{~g}$ of freeze-dried and homogenisized subsamples of originally $2 \mathrm{~cm}$ thick intervals have been combusted in a muffle furnace subsequently for $4 \mathrm{~h}$ at $550^{\circ} \mathrm{C}$ (oxidation of organic matter) and $950^{\circ} \mathrm{C}$ (combustion of the carbonate). The weight loss during the oxidations was measured by weighing the subsamples before and after each burning process. The LOI (given as a percentage) was then calculated using the formulas published by Heiri et al. (2001). Although there are several factors affecting the LOI results (e.g. sample size, exposure time, position of samples in the furnace), this relatively cheap and fast method yields a reliable estimation of the organic carbon and carbonate contents in the sediments (Heiri et al., 2001).

\section{Diatom slides}

Diatom slides were prepared in $5 \mathrm{~cm}$ intervals from freeze-dried bulk sediment which was treated successively with hydrogen peroxide, hydrochloric acid and nitric acid, in order to remove all organic and carbonate components (Cremer et al., 2001). Slides were prepared employing the sedimentation tray method described by Battarbee (1973). Cover-glasses were mounted on slides using the high refraction mountant Naphrax ${ }^{\circledR}$. Diatom identification and counting was carried out at a magnification of $\times 1000$ using an Olympus BX51 microscope equipped with Nomarski optics. As far as possible, a minimum of 300 valves 


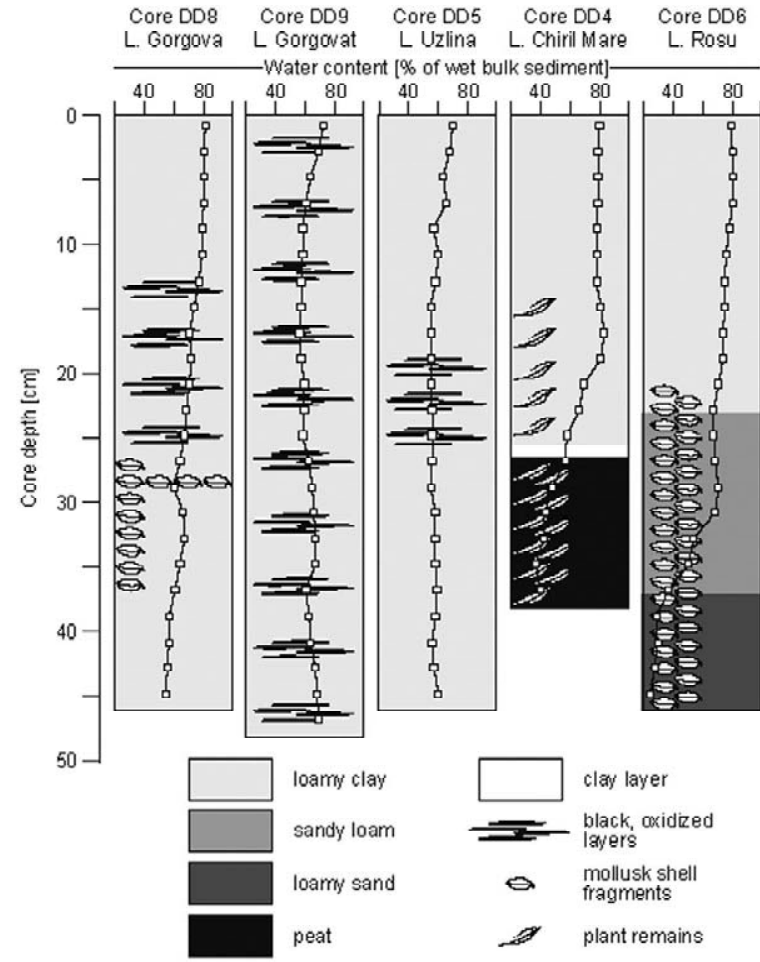

Figure 2. Lithology and water content in short sediment cores from five Danube Delta lakes.

were counted. The identification of diatom species was mainly based on Krammer \& Lange-Bertalot (1991, 1999a,b, 2000).

\section{Results and discussion}

Lithology, radiocesium $\left({ }^{137} \mathrm{Cs}\right)$ concentration and loss on ignition (LOI)

\section{Lithology}

The five sediment cores consist mainly of a muddy loamy clay with inserted black oxidized layers (Fig. 2). The basal sections of cores DD4 from L. Chiril Mare and DD6 from L. Roşu are characterized by thick peat and sand layers, respectively. Although it was not the aim of this study to apply complex sedimentological methods, the rough and rather qualitative lithological description of the five cores given in Figure 2 clearly shows that there is a large variety of sedimentological settings present within the Danube Delta lakes. However, whereas the surface deposits in the Danube Delta are comprehensively mapped (Munteanu \& Curelariu, 1996) there is only limited

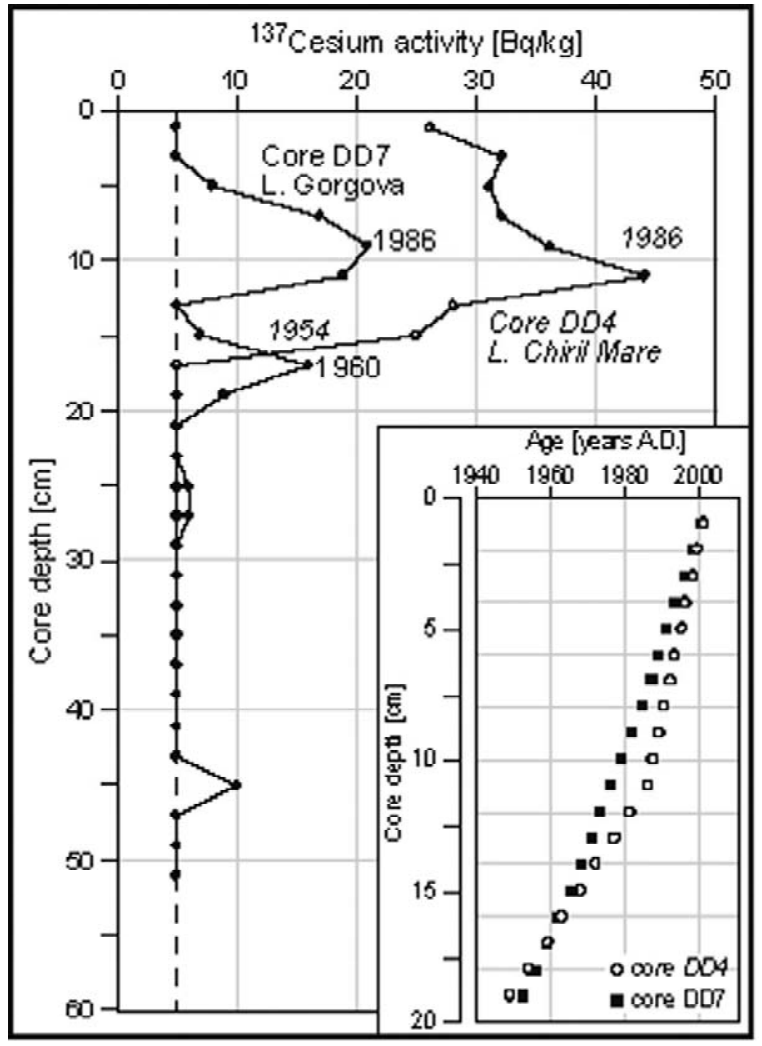

Figure 3. Radiocesium activities in two selected lake sediment cores from the Danube Delta. The dashed line represents the background ${ }^{137} \mathrm{Cs}$ activity. Methods applied (see also text): core DD4, single measurements using a Germanium detector, measured at the Institute for Inland Water Management and Wastewater Treatment (RIZA, Lelystad, The Netherlands); core DD7, entire-core measurements using the PHAROS detector, measured at the Nuclear Geophysics Division of the Kernfysisch Versneller Instituut (KVI, Groningen, The Netherlands). The inset shows the age-depth relationship in both cores for the past 50 years.

information available on the vertical structure of soils and sediments (e.g. Pfannenstiel, 1950; Ghenea \& Mihailescu, 1991), particularly of those representing the past few hundred years. The core lithology is also reflected in the water content which is generally high in the sections consisting of loamy clay and amounts up to $80 \%$ of the wet weight (Fig. 2). The basal peat and sand sections in L. Chiril Mare and L. Roşu, respectively, have a distinctly lower water content of $40-50 \%$ (Fig. 2).

\section{Radiocesium $\left({ }^{137} \mathrm{Cs}\right)$ dating}

Radiocesium activities in the sediments of L. Gorgova and L. Chiril Mare are summarized in Figure 3. Both sediment cores show rather low radiocesium activities and at least one distinct peak reflecting most 
likely the readionuclide fallout as a consequence of the Chernobyl nuclear power plant accident in 1986. The difference in the radiocesium activities between the two cores might be due to the two methods applied for radiocesium determination (see chapter 'Materials and methods'). Core DD7 from L. Gorgova shows also a minor peak between 16 and $18 \mathrm{~cm}$ core depth which probably reflects regular atmospheric nuclear weapon tests that started from early 1960s (Fig. 3). This lower peak is not clearly visible in core DD4 from L. Chiril Mare and it might be speculated that the onset of nuclear bomb testing in the early 1950 s is reflected in the increase of the radiocesium activity between 15 and 16 $\mathrm{cm}$ core depth. Core DD4 was also measured on ${ }^{210} \mathrm{~Pb}$ activities which, however, are relatively low and vary between $112 \mathrm{~Bq} \mathrm{~kg}^{-1}$ at $4-6 \mathrm{~cm}$ core depth and $7 \mathrm{~Bq}$ $\mathrm{kg}^{-1}$ at $34-36 \mathrm{~cm}$ core depth.

The radiocesium activities measured in cores DD4 and DD7 are by factor three to six lower compared to published values for other lacustrine cores from the Danube Delta (Duliu et al., 1996; Winkels et al., 1998; Dinescu \& Duliu, 2001). This could be due to the fact that the results in both cores were not corrected for sediment density and/or that the BismutGermanium-Oxide detectors used for core DD7 in the PHAROS technique (see chapter 'Materials and methods') have a lower resolution than the High Purity Germanium detector that was used for core DD4. In general, the concentration of fallout radionuclides in lake sediments depends on various factors including the atmospheric flux to the catchment and the lakes, transport processes between catchment and lakes, the loss via outflow and the residence time of water in lakes (Appleby, 2001), all of which certainly contributed to the observed patterns of radiocesium activity in both cores.

Sedimentation rates calculated for both lakes based on the radiocesium activity are shown in Table 3 . The generally low ${ }^{137} \mathrm{Cs}$ activities make it difficult to calculate dates for the two cores with the consequence that the dates given in Figures 3 and 7 should be regarded with some caution but, nevertheless, provide a good estimate of the sedimentation rates. Sedimentation rates are distinctly higher during the past 15 years compared to the older layers. Moreover, the modern sedimentation rate in L. Chiril Mare is clearly higher than the respective rate in L. Gorgova $(0.70 \mathrm{~cm}$ compared to $0.47 \mathrm{~cm}$ per year) but is lower in pre-1986 times $(0.20 \mathrm{~cm}$ compared to $0.35 \mathrm{~cm}$ per year). The sedimentation rates determined in the present study are in the same range as rates calculated for L. Furtuna,
Table 3. Comparison of calculated sedimentation rates from lakes of the Danube Delta

\begin{tabular}{lcc}
\hline \multicolumn{1}{c}{ Lake } & Period & $\begin{array}{c}\text { Sedimentation rate } \\
\text { [cm/year] }\end{array}$ \\
\hline & Cremer et al. (this study) \\
L. Gorgova & $1986-2002$ & $0.47 \pm 0.05$ \\
& $1960-1986$ & $0.35 \pm 0.07$ \\
L. Chiril Mare & $1986-2002$ & 0.70 \\
& $1953-1986$ & 0.20 \\
L. Matita & Duliu et al. (2001) & ca. 0.15 \\
& $1963-1994$ & 0.81 \\
L. Furtuna & Dinescu \& Duliu (1998) & 0.60 \\
L. Lung & $1930-1996$ & 0.80 \\
L. Mesteru & $1930-1996$ & $\sim 1$ \\
& $1930-1996$ & $\sim 5-10$ \\
L. Uzlina & Winkels et al. (1998) & \\
Unnamed lake 1 & $1940-1994$ & \\
(western delta) & $1940-1994$ & \\
Unnamed lake 2 & $1940-1994$ & \\
(western delta) & & \\
\hline
\end{tabular}

L. Lung, and L. Mesteru by Dinescu \& Duliu (1998) and for L. Uzlina by Winkels et al. (1998) (Table 3), but they are distinctly higher than the rate calculated for L. Matita in the northern Danube Delta (Duliu et al., 1996). On the other hand, Winkels et al. (1998) report significantly higher sedimentation rates between 5 and $10 \mathrm{~cm} /$ year from two lakes located in the western part of the Danube Delta.

Radiocesium activities and resulting sedimentation rates in cores DD4 and DD7 suggest a reliable agedepth relationship for the past 50 years (Fig. 3). Taking into account the distinctly varying inter-lake and intralake sedimentation rates (Table 3), calculated pre-1950 sedimentation rates and dates would be rather speculative as there are no distinct and reliable time markers preserved. However, the few published radiocesium activities and sedimentation rates suggest variable and dynamic sedimentation processes in the Danube Delta lakes.

\section{Loss on ignition (LOI)}

The heterogenous nature of depositional lake environments within the Danube Delta is also confirmed by the LOI measurements carried out on four cores. As mentioned above, the LOI procedure is a low-cost and relatively time-saving method to quantitatively estimate the contents of organic carbon and carbonate in 

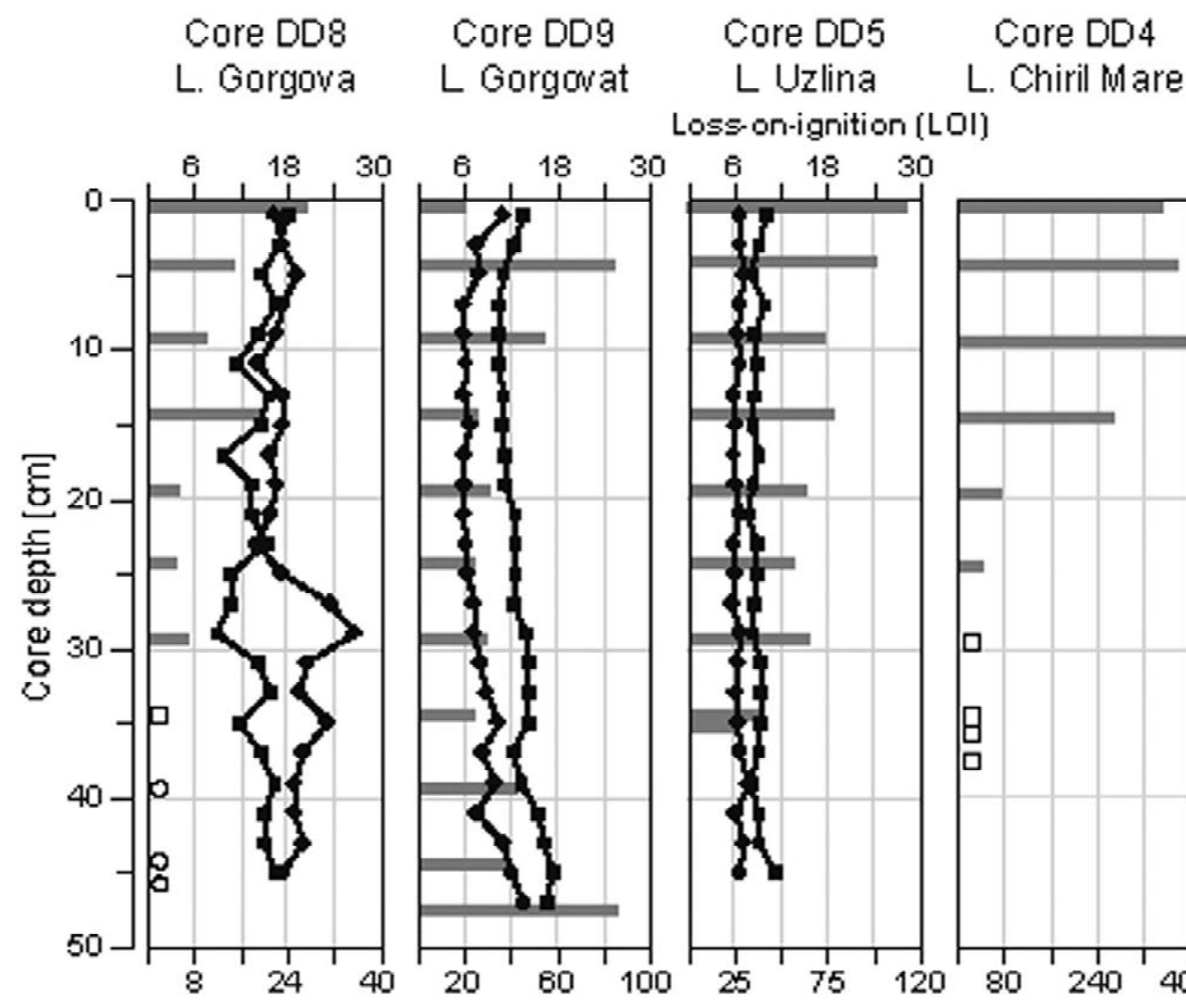

Core DD6

Loss-on-ignition (LOI)

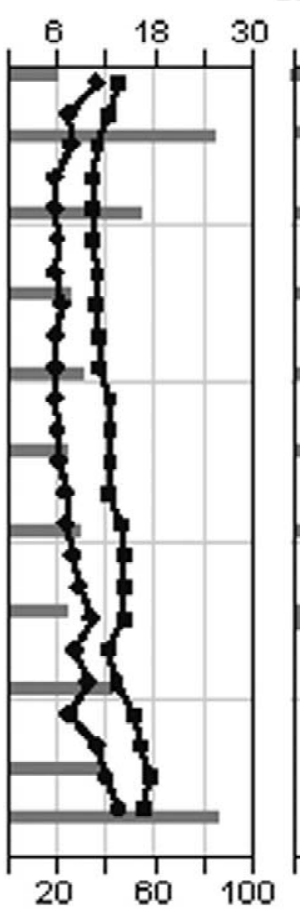

$\stackrel{6}{1}, 18,30$
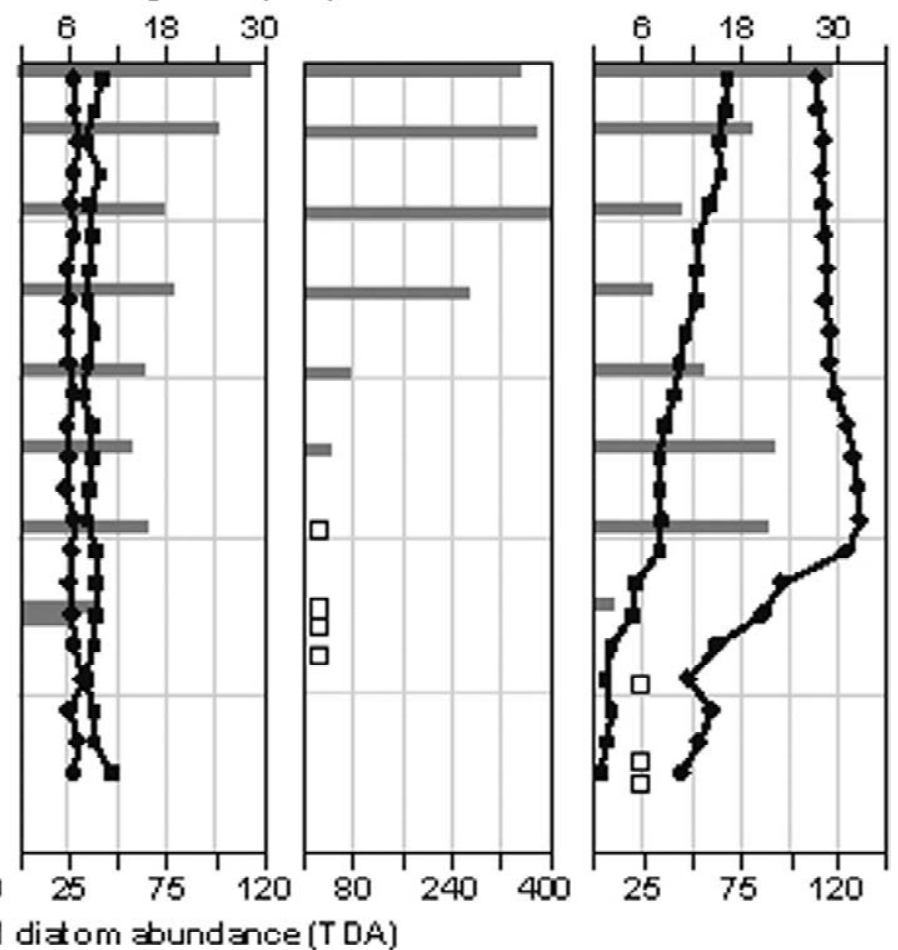

LOI $550[\% \mathrm{DW}]$

of $950[\% \mathrm{DW}]$

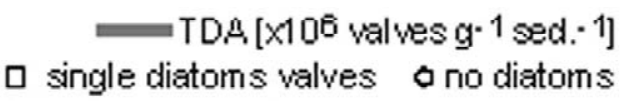

Figure 4. Loss on ignition (LOI) and total diatom abundance (TDA) data in short sediment cores from five Danube Delta lakes.

sediments (Heiri et al., 2001). The LOI curves presented in Figure 4 show disparate trends regarding both the absolute LOI values and the downcore variation between the four sediment cores. Lake Gorgovat and L. Uzlina are characterized by LOI 550 values of 12$18 \%$ and $6-12 \%$, respectively, and both show LOI 950 values of $6-12 \%$ (Fig. 4). The downcore variation of both LOI indicators is relatively low in both cores which may indicate a relatively stable depositional environment in both lakes during the past century.

On the other hand, the LOI records in L. Gorgova and L. Roşu show distinct downcore variability. Whereas the LOI 550 in L. Gorgova uniformly varies between 12 and $18 \%$, there is a shift in the LOI 950 visible at $25 \mathrm{~cm}$ core depth with distinctly increased values below this level (Fig. 4). This observation is in accordance with the lithology of core DD8 showing distinctly identifiable layers of mollusk shell fragments between 27 and $37 \mathrm{~cm}$ core depth (Fig. 2).
Clearest trends are represented in core DD6 from L. Roşu of which LOI 550 record gradually decreases from $18 \%$ present in the clayey top layer of the core towards $1 \%$ in the sandy bottom core part (Fig. 4). An even more obvious trend is visible in the carbonate record of core DD6: the LOI 950 values fluctuate around $30 \%$ in the upper $30 \mathrm{~cm}$ of the core and shift towards values around $12 \%$ in the interval $30-40 \mathrm{~cm}$ depth. This LOI pattern might match with the lithology of core DD6 (Fig. 2) which shows a relatively high sand proportion below $25 \mathrm{~cm}$ core depth and, moreover, a clearly lower water content in the basal core section. However, we do not have any good explanation for the distinct decrease in LOI 950 below $30 \mathrm{~cm}$ in core DD6 despite the presence of high proportions of mollusk shells (Fig. 2) which would suggest an increased carbonate content.

In summary, the results of the LOI measurements are in good accordance with the lithological findings 
of the sediment cores and they confirm the diversity of depositional lake environments within the Danube Delta.

\section{Composition of the diatom flora}

The present work is the first comprehensive study of the modern and historical diatom flora from lakes located in the Romanian Danube Delta. A total of 234 diatom taxa representing 57 genera could be identified in modern lake sediments from the Danube Delta. All taxa are listed in Appendix I according to current taxonomical literature. The high number of genera reflect the recent trend of splitting up almost all diatom genera based on new micromorphological, physiological and genetical insights due to improved microscopic and molecular techniques.

\section{Downcore diatom assemblages}

Diatoms are present throughout sediment cores DD9 (L. Gorgovaţ) and DD5 (L. Uzlina) indicating a continuous depositional environment in both lakes. On the other hand, the bottom core layers in L. Gorgova, L. Chiril Mare, and L. Roşu show only minor diatom content or even are completely barren, thus indicating events that have possibly prevented a continuous sedimentation (Fig. 4). The total diatom abundance (TDA) shows no uniform trend in all five sediment cores. The maximum TDA values vary between $400 \times 10^{6}$ valves $\mathrm{g}^{-1}$ dry sed. in core DD4 from L. Chiril Mare and $28 \times 10^{6}$ valves $\mathrm{g}^{-1}$ dry sed. in core DD8 from $\mathrm{L}$. Gorgova (Fig. 4), thus representing inter-lake variability in sedimentation patterns and possibly also diatom bioproductivity. There are also remarkable TDA fluctuations visible within the single cores. Whereas in the cores from L. Gorgova, L. Uzlina, and L. Chiril Mare the TDA decreases with core depth, the cores from L. Gorgovaţ and L. Roşu are characterized by clearly increased TDA values in both the top and bottom core layers (Fig. 4). These findings demonstrate that the productivity conditions in the lakes may have changed drastically over the time represented by these cores.

Figures 5 and 6 summarize the diatom downcore succession based on the relative abundance of single diatom species. The graphs show all taxa that achieve a relative abundance of $5 \%$ in at least one subsample. The number of taxa that meet this criterion ranges between 15 taxa in core DD6 from L. Roşu and just seven taxa in core DD4 from L. Chiril Mare. The diatom downcore succession patterns are briefly described hereafter:
Lake Gorgova (core DD8, Fig. 5). There is a clear boundary in this core at $20 \mathrm{~cm}$ core depth: below this boundary, between 20 and $30 \mathrm{~cm}$ core depth, the diatom assemblage is dominated by Staurosira construens Ehrenberg and varieties (see Appendix 1) and Staurosirella pinnata (Ehrenberg) Williams et Round, whereas above this layer Aulacoseira granulata (Ehrenberg) Simonsen, Nitzschia solita Hustedt and Stephanodiscus hantzschii Grunow and associated species are most abundant. There is a clear maximum in the relative abundance of Cocconeis placentula Ehrenberg in the topmost layer.

Lake Gorgovaț (core DD9, Fig. 5). As in core DD8, there is a clear shift in the composition of the diatom assemblage at $25 \mathrm{~cm}$ core depth. Below this layer $S$. construens and $S$. pinnata are the predominating species, whereas above this boundary A. granulata, Cyclotella meneghiniana Kützing and the S. hantzschii group are most abundant. The topmost layer shows maximum relative abundance of $C$. placentula and Fragilaria vaucheriae (Kützing) Petersen.

Lake Uzlina (core DD5, Fig. 5). In this core the diatom assemblage below $18 \mathrm{~cm}$ core depth is predominated by A. granulata, Aulacoseira subarctica (Müller) Harworth and the $S$. hantzschii group. Above this boundary, C. placentula, F. vaucheriae and Thalassiosira visurgis Hustedt have highest relative abundance. Both Cyclostephanos invisitatus (Hohn et Hellerman) Theriot, Stoermer et Håkansson and C. meneghiniana occur in relatively high abundances throughout the core but do not show any distinct trends.

Lake Chiril Mare (core DD4, Fig. 6). There are only seven species in core DD4 that meet the $5 \%$ criterion. The complete core, except for the sequence between 24 and $30 \mathrm{~cm}$ core depth, is clearly dominated by the three fragilarioid species Pseudostaurosira brevistriata (Grunow) Williams et Round, S. construens, and $S$. pinnata. The interval between 24 and $30 \mathrm{~cm}$ is characterized by increased relative abundance of A. granulata, Epithemia adnata (Kützing) Brébisson and E. turgida (Ehrenberg) Kützing. Furthermore, the $S$. hantzschii group occurs in increased relative abundance in the uppermost $5 \mathrm{~cm}$ of the core.

Lake Roşu (core DD6, Fig. 6). This core shows the highest number of species that occur at a relative abundance of $5 \%$ in at least one subsample. The core can roughly be subdivided into three intervals. The basal layer up to $35 \mathrm{~cm}$ core depth is predominated by $S$. pinnata, $P$. brevistriata and two species of the genus Amphora. The interval between 10 and $30 \mathrm{~cm}$ core depth shows highest relative abundance 


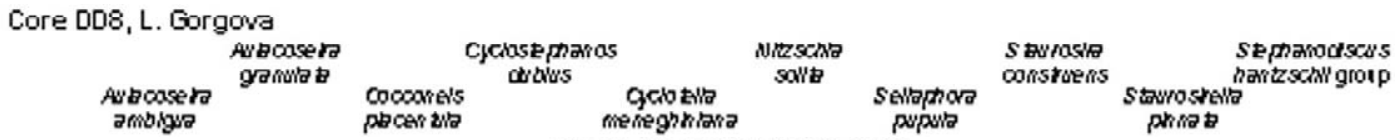

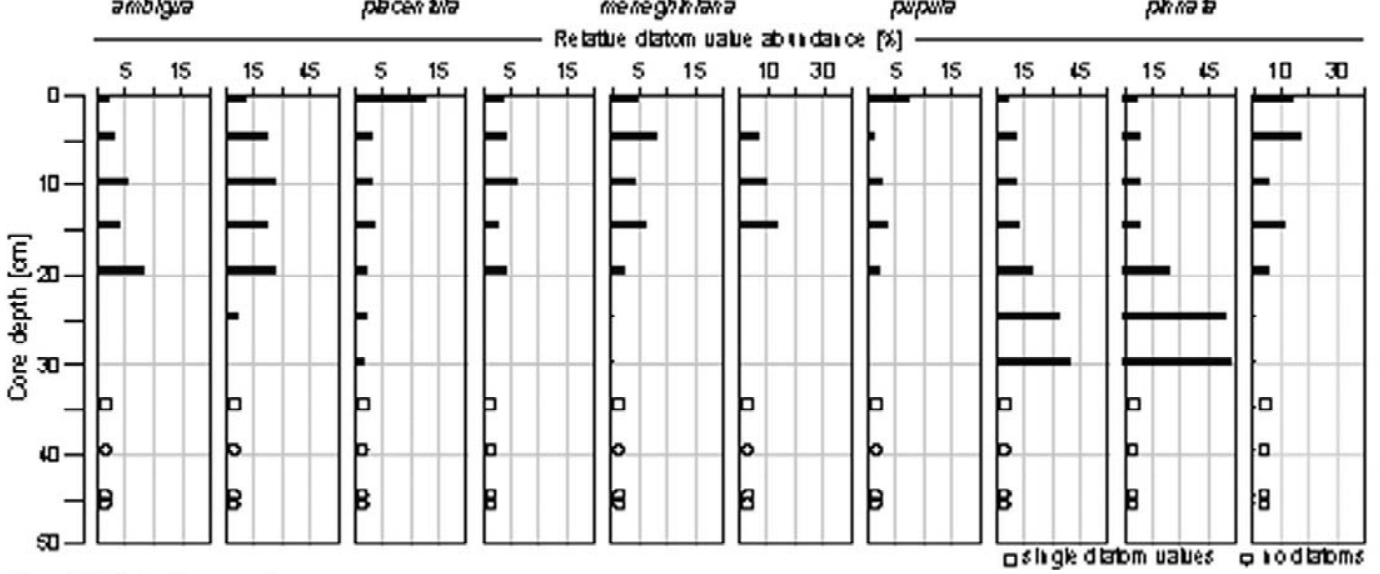

Core DDS, L. Gorgovet
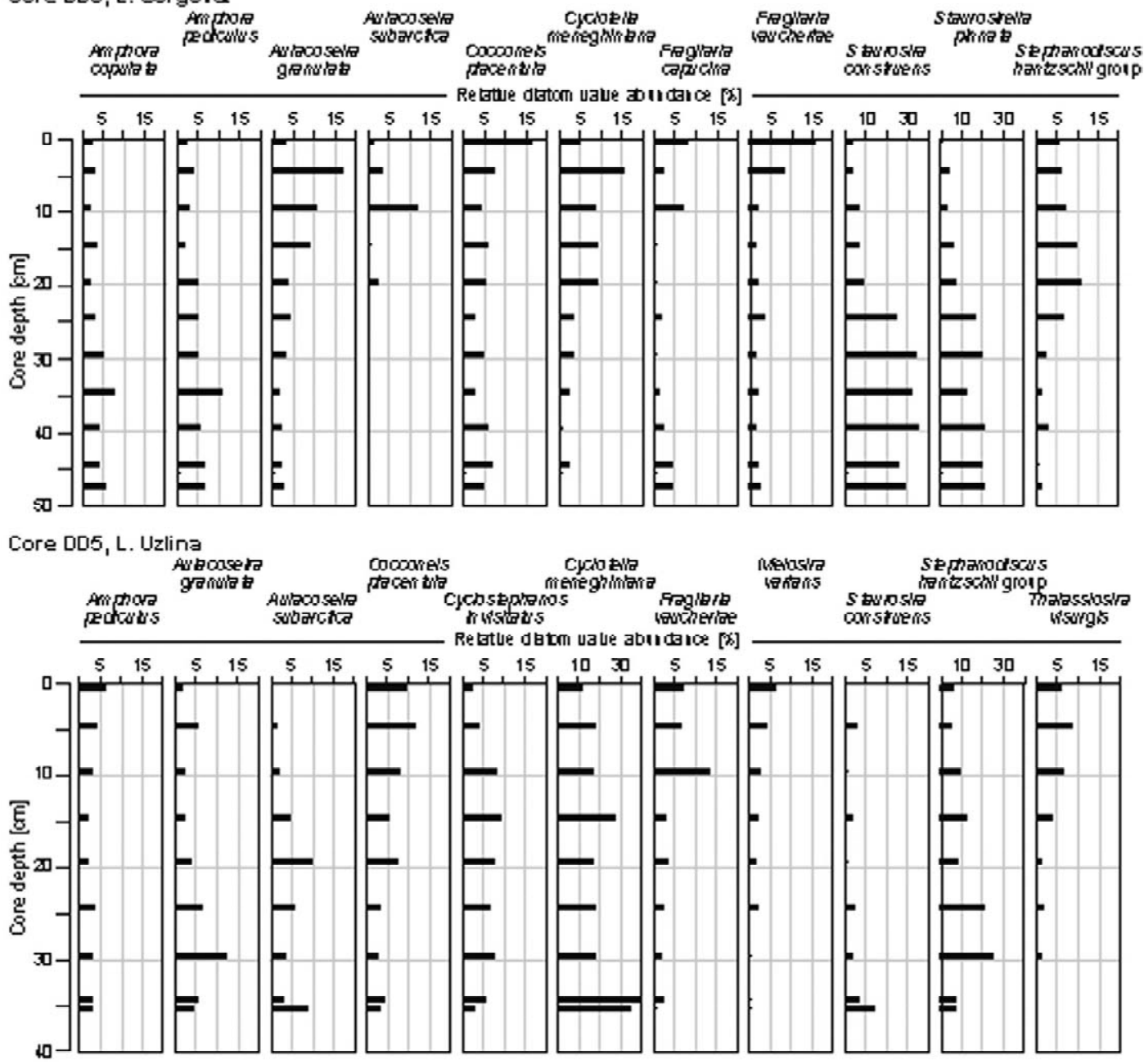

Figure 5. Composition of diatom assemblages in short sediment cores from L. Gorgova, L. Gorgovaţ, and L. Uzlina. All taxa are considered that achieve a minimum of 5\% relative abundance in at least one subsample. The Stephanodiscus hantzschii group also includes S. minutulus and S. parvus. 

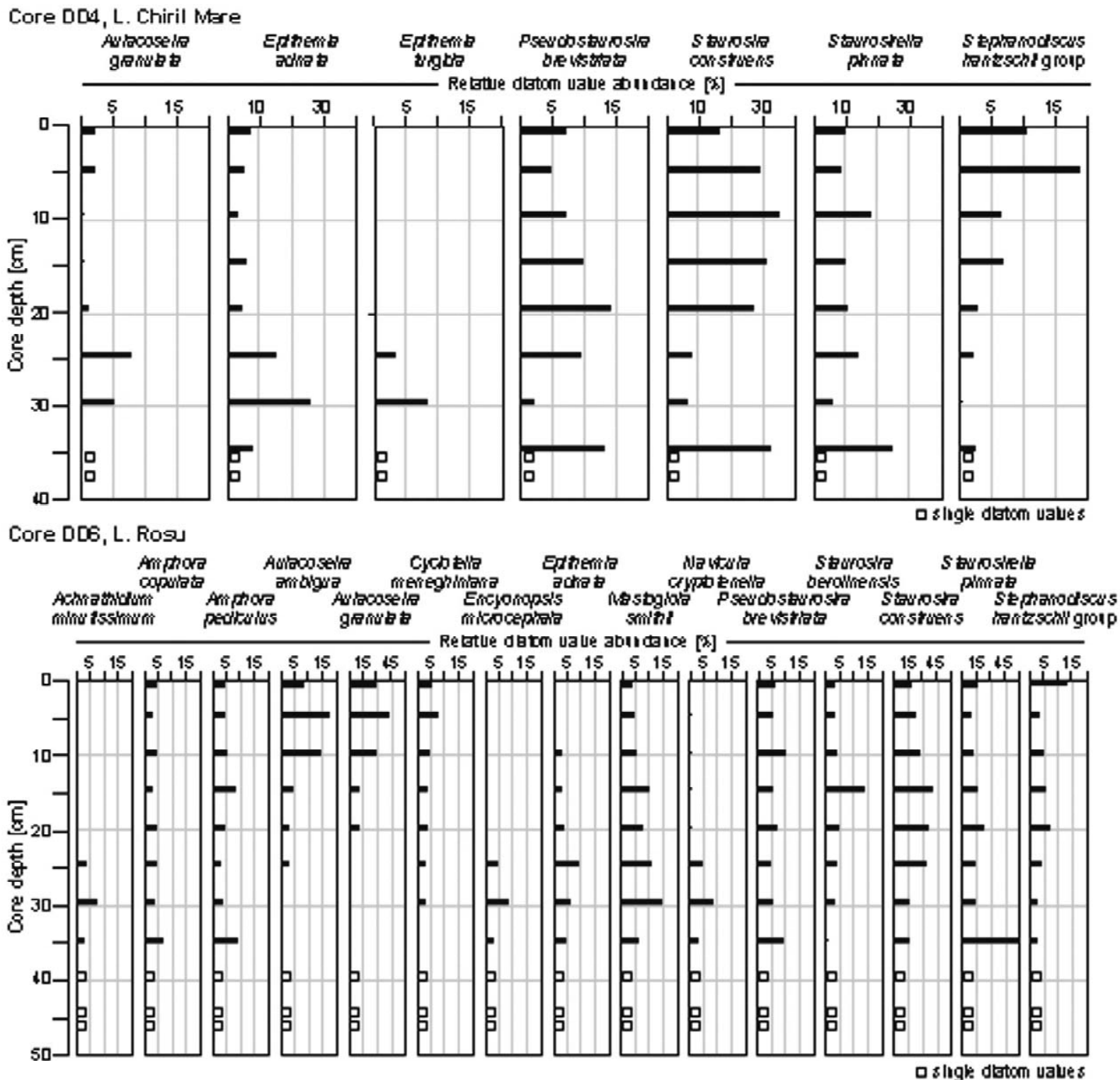

Figure 6. Composition of diatom assemblages in short sediment cores from L. Chiril Mare and L. Roşu. All taxa are considered that achieve a minimum of 5\% relative abundance in at least one subsample. The Stephanodiscus hantzschii group also includes S. minutulus and S. parvus.

of S. construens, S. pinnata and Mastogloia smithii Thwaites. The uppermost layer $(0-10 \mathrm{~cm})$ is characterized by the predominance of $A$. granulata and $A$. ambigua (Grunow) Simonsen.

A comparison of the diatom assemblages in the five sediment cores reveals significant differences with regard to the species composition, thus reflecting local, lake-specific limnological conditions. An inter-lake diatom comparison is best possible looking at the three species that do occur in significant relative abundance in all five cores (Fig. 7): A. granulata, S. construens and the $S$. hantzschii group. Figure 7 shows clear differences in the occurrence of the three species in preand post-1960 times. On the other hand, there is no clear inter-lake trend visible that could be related to the geographical location of the lakes in the Danube Delta. Staurosira construens, for example, a cosmopolitan benthic and epiphytic diatom species, shows highest relative abundance in pre-1960 times in $\mathrm{L}$. Gorgova and L. Gorgovaţ and in post-1960 times in 

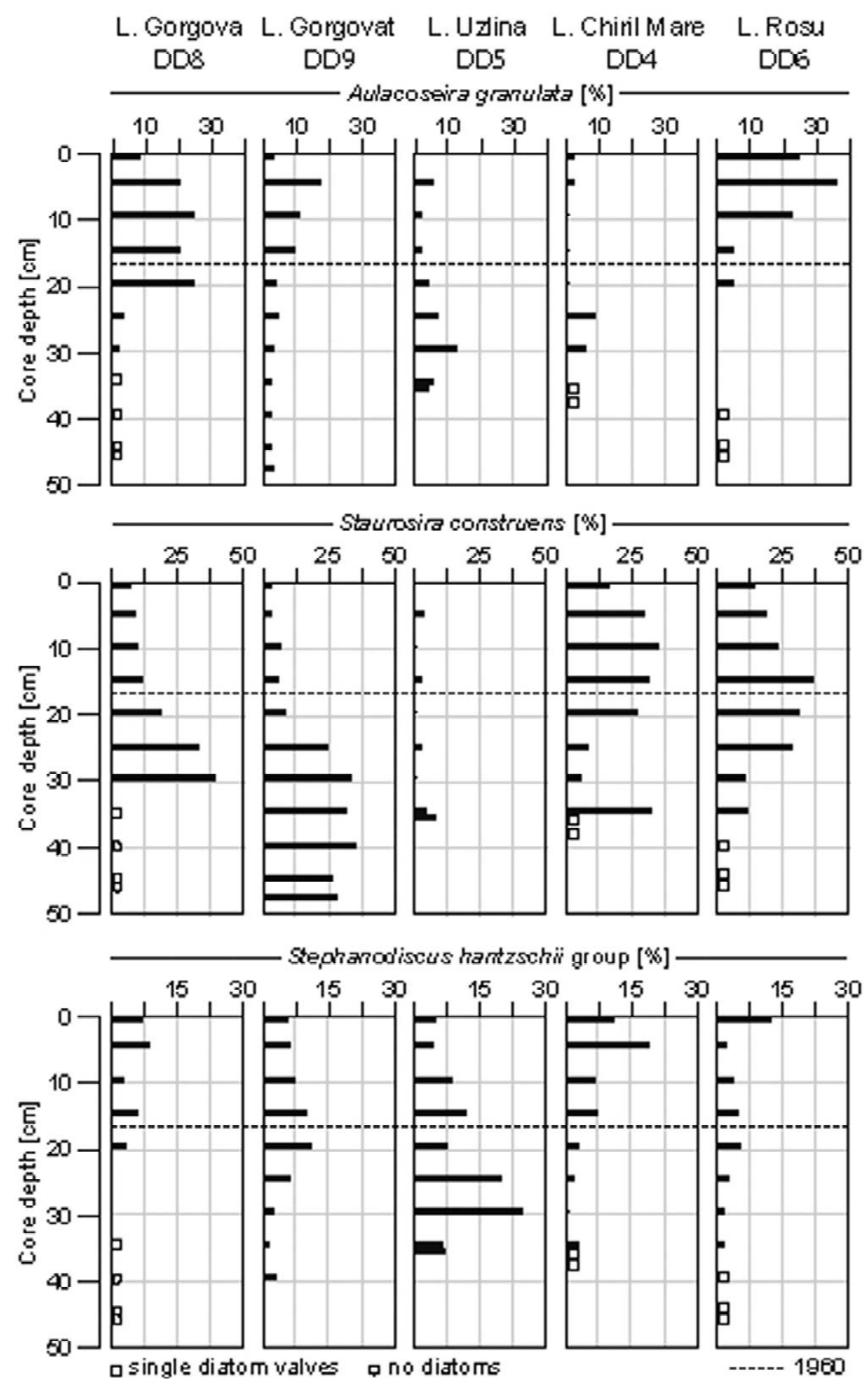

Figure 7. Comparison of short sediment cores from five Danube Delta lakes regarding the downcore relative abundance of the three diatom taxa frequently occurring in all lakes. The dashed line marks the year 1960 based on radiocesium determination in cores DD4 and DD7 (see Fig. 3). The Stephanodiscus hantzschii group also includes S. minutulus and S. parvus. 
L. Chiril Mare; there is no clear trend visible in the core from L. Roşu and S. construens is only of minor importance in L. Uzlina. Aulacoseira granulata, a cosmopolitan tychoplanktonic species, shows highest occurrence in post-1960 sediments of L. Gorgova and L. Roşu whereas the $S$. hantzschii group, consisting also of cosmopolitan planktic diatoms, does particularly occur in pre-1960 sediments of L. Uzlina and post-1960 times in L. Chiril Mare (Fig. 7).

The variability of the sedimentary diatom distribution patterns is also supported by the phytoplankton occurrence. Phytoplankton surveys carried out in 1997 and 1998 in 13 selected lakes of the Danube Delta show that there is a large seasonal and interannual variability in the composition of the diatom communities (Ibelings et al., 2000). In both years, diatoms together with blue-green algae were the most abundant algae, based on cell number counts in water samples. However, the occurrence of blooms and the genera and species that were most abundant, were different from year to year. For example, L. Roşu had a combined diatom-blue-green algae bloom in July 1997 , whereas in 1998 there was a diatom bloom in April and blue-green algae did not occur at all (Ibelings et al., 2000).

In summary, the diatom downcore assemblages demonstrate first, that there are no general trends and gradients visible in the species composition of the delta lakes, and second, as a consequence, that the modern distribution pattern of diatom communities must be triggered by a variety of lake-specific hydrological conditions. Furtheron, it is rather evident that the modern spatial distribution of diatom communities within the Danube Delta is not reflected in the lake classification system suggested by Buijse et al. (2002) (Table 2), meaning that the different diatom communities cannot be assigned to a certain lake type. This suggests that the lake ecosystems within the Danube Delta are enormously dynamic and variable and, therefore, it might be problematic to arrange them in a consistent classification system.

\section{Potential of diatom assemblages as indicator for past environmental changes}

More or less distinct changes in the diatom species composition are visible in all investigated cores (Figs 5, 6 and 7). The diatom downcore successions show that environmental changes undoubtedly must have been present during the past century. However, because the modern limnology and the interplay between biotic and abiotic factors in the delta lakes are not yet completely understood, it is difficult to specify those environmental changes that could have been responsible for the observed changes in the diatom assemblages. Possible causes for the observed spatial and temporal distribution pattern of diatom assemblages could be diverse and may include, for example, changes in lakewater quality, the presence of submerged vegetation, turbidity, physico-chemical conditions, water depth and inter-biota relationships (e.g. grazing).

\section{Past changes in trophic state}

The main focus of this pilot study was to check whether the diatom assemblages have the potential for reconstructing the eutrophication history of the delta lakes. Diatom assemblages are since long time used as indicators for historical changes in the trophic state of lakes (see Hall \& Smol, 1999, for a review) and there are several case studies available from various regions in Europe that demonstrate lake eutrophication and restoration trends over the past 120 years (e.g. Lotter, 1998). Lakes within the Danube Delta are also believed to have suffered substantial eutrophication since the 1960s although the available data that could confirm this are relatively poor. The average total phosphorus concentration in the delta lakes ranges from 80 to $150 \mu \mathrm{g} / \mathrm{l}$ stating that most lakes recently are eutrophic or even hypertrophic (Oosterberg \& Bogdan, 2000). Whereas the inter-lake variability in the total phosphorus content is relatively small, there is considerable seasonal variation within single lakes. This trend is also visible in other parameters, e.g. the nitrogen, chlorophyll and suspended solid concentrations (Oosterberg \& Bogdan, 2000).

In order to estimate the potenial of the delta lake diatom assemblages for a reconstruction of past eutrophication trends, the trophic state of all relevant diatom species has been compiled (Table 4). The trophic affinities were taken from van Dam et al. (1994) who listed the freshwater diatoms of the Netherlands and their autecological preferences based on own observations and literature data. The most abundant diatoms occurring in the sediments of the delta lakes are mesoto eutraphentic, some even hypertraphentic taxa (Table 4). Considering the predominance of these diatom taxa in all five sediment cores (Figs 5 and 6), it becomes clear that the investigated lakes must have been mesoto eutrophic throughout the timespan reflected by the cores. 
Table 4. Trophic affinities of the most abundant diatom species in lake sediments from the Danube Delta (compiled after van Dam et al., 1994)

\begin{tabular}{|c|c|c|}
\hline Species & Trophic state & Ecology \\
\hline Achnanthidium minutissimum & Oligo-eutraphentic & Benthic \\
\hline Amphora copulata & Eutraphentic & Benthic \\
\hline Amphora pediculus & Eutraphentic & Benthic \\
\hline Aulacoseira ambigua & Eutraphentic & Planktic \\
\hline Aulacoseira granulata & Eutraphentic & Planktic, tychoplanktonic \\
\hline Aulacoseira subarctica & Oligo-mesotraphentic & Planktic \\
\hline Cocconeis placentula & Eutraphentic & Benthic \\
\hline Cyclostephanos dubius & Eutraphentic & Planktic \\
\hline Cyclostephanos invisitatus & ? Hypereutraphentic & Planktic \\
\hline Cyclotella meneghiniana & Eutraphentic & Tychoplanktonic \\
\hline Encyonopsis microcephala & Meso-eutraphentic & Benthic \\
\hline Epithemia adnata & Meso-eutraphentic & Benthic \\
\hline Epithemia turgida & Meso-eutraphentic & Benthic \\
\hline Fragilaria capucina & Mesotraphentic & Benthic \\
\hline Fragilaria vaucheriae & Eutraphentic & Benthic \\
\hline Mastogloia smithii & Eutraphentic & Benthic \\
\hline Melosira varians & Eutraphentic & Planktic \\
\hline Navicula cryptotenella & Oligo-eutraphentic & Benthic \\
\hline Nitzschia solita & Eutraphentic & Benthic \\
\hline Pseudostaurosira brevistriata & Oligo-eutraphentic & Benthic \\
\hline Sellaphora pupula & Mesotraphentic & Benthic \\
\hline Staurosira berolinensis & Hypereutraphentic & Planktic \\
\hline Staurosira construens & Meso-eutraphentic & Benthic \\
\hline Staurosirella pinnata & Oligo-eutraphentic & Benthic \\
\hline Stephanodiscus hantzschii & Hypereutraphentic & Planktic \\
\hline Stephanodiscus minutulus & Hypereutraphentic & Planktic \\
\hline Stephanodiscus parvus & Hypereutraphentic & Planktic \\
\hline Thalassiosira visurgis & No Information available & Planktic \\
\hline
\end{tabular}

The meso- to eutraphentic nature of the most abundant diatom taxa throughout the entire sediment cores indicates that eutrophication likely took place much earlier than the 1950s. There are a few arguments that might support the hypothesis that waters in the Danube Delta are meso- to eutrophic since very long time. The Danube Delta has always been the terminus of the Danube River which drains vast regions of eastern Europe and consequently, constantly received a surplus of nutrients. This 'natural eutrophication process' has been certainly strongly amplified since humans started to cultivate the land in the catchment of the Danube River. Early human impact certainly included agricultural activities (e.g. ploughing of fields) which led to an increase of land erosion and consequently, enhanced nutrient supply. An intensification of these processes, possibly due to increased popoulation since the Greek and Ro- man periods, might have led to meso- to eutrophic conditions in the Danube Delta since that time. Nevertheless, it is rather likely that the nutrient input into the Danube Delta was highest during the past 50 years due to increased population and industrial activities. However, changes from meso- to eutrophic and from eu- to hypertrophic conditions are hardly reflected in the diatom assemblages.

\section{Conclusions}

The studied sediment cores from five shallow lakes in the Danube Delta reveal a diverse diatom flora and large spatial and temporal variations in both the occurrence and species composition of the diatom assemblages. 
However, at present, it is rather unclear how the spatial and temporal distribution of phytoplankton and periphyton communities in Danube Delta lakes is controlled. The available database of limnological parameters is still relatively little and does not include all lakes in the study area and, consequently, has to be enlarged during future monitoring campaigns. The sedimentary diatom successions likely do not reflect eutrophication trends in the delta lakes indicated by the aspect that all abundant diatoms in the downcore assemblages are meso- to eutraphentic species. Most likely, the delta lakes as the 'end of the pipe' of the Danube River are meso- to eutrophic since late-Holocene times.

The present investigation clearly emphasizes the view that each of the Danube Delta lakes is a unique mini-ecosystem with local and lake-specific geomorphological, hydrological, sedimentological and biological conditions.

\section{Acknowledgements}

This pilot study is part of a long-term survey programme of lake habitats and ecological gradients within the Danube Delta and should assay the potential of diatom floras for palaeolimnological reconstructions in floodplain lakes. The programme is coordinated by the Danube Delta National Institute (DDNI, Tulcea, Romania) and the Institute for Inland Water Management and Wastewater Treatment (RIZA, Lelystad, The Netherlands). We thank the responsible authorities and the crew of the houseboat for the kind and efficient cooperation during field work. The paper greatly benefitted from comments of John P. Smol and an anonymous reviewer.

\section{References}

Appleby, P. G., 2001. Chronostratigraphic techniques in recent sediments. In Last, W. M. \& J. P. Smol (eds), Tracking Environmental Change Using Lake Sediments. Volume I: Basin Analysis, Coring and Chronological Techniques. Kluwer Academic Publishers, Dordrecht, The Netherlands: 171-203.

Battarbee, R. W., 1973. A new method for estimation of absolute microfossil numbers, with reference especially to diatoms. Limnol. Oceanogr. 18: 647-653.

Buijse, A. D., H. Coops, M. staras, L. H. Jans, G. J. Van Geest, R. E. Grifts, B. W. Ibelings, W. Oosterberg \& F. C. J. M. Roozen, 2002. Restoration strategies for river floodplains along large lowland rivers in Europe. Freshwat. Biol. 47: 889-436.
Coops, H., J. Hanganu, M. Tudor \& W. Oosterberg, 1999. Classification of Danube Delta lakes based on aquatic vegetation and turbidity. Hydrobiologia 415: 187-191.

Cremer, H., B. Wagner, M. Melles \& H.-W. Hubberten, 2001a. The postglacial environmental development of Raffles Sø, East Greenland: inferences from a 10000 year diatom record. J. Paleolimnol. 26: 67-87.

Dinescu, L. C. \& O. G. Duliu, 2001. Heavy metal pollution of some Danube Delta lacustrine sediments studied by neutron activation analysis. Appl. Radiation and Isotopes 54: 853-859.

Duliu, O. G., L. C. Dinescu, M. C. Dinescu, R. D. Dorcioman, N. Gh. Mihãilescu \& I. S. Vanghelie, 1996. Some considerations concerning $137 \mathrm{Cs}$ vertical profile in the Danube Delta: Matita Lake core. Sci. Tot. Envir. 188: 9-14.

Ghenea, C. \& N. Mihailescu, 1991. Palaeogeography of the Lower Danube Valley and the Danube Delta during the last 15000 years. In Starkel, L., K. J. Gregory \& J. B. Thornes (eds), Temperate Palaeohydrology. John Wiley and Sons, Chichester: 343-364.

Hall, R. I. \& J. P. Smol, 1999. Diatoms as indicators of lake eutrophication. In Stoermer, E. F. \& J. P. Smol (eds), The Diatoms: Applications for the Environmental and Earth Sciences. Cambridge University Press, Cambridge: 128-168.

Hay, M., N. Michelutti \& J. P. Smol, 2000. Ecological patterns of diatom assemblages from Mackenzie Delta lakes, Northwest Territories, Canada. Can. J. Bot. 78: 19-33.

Heiri, O., A. F. Lotter \& G. Lemcke, 2001. Loss on ignition as a method for estimating organic and carbonate content in sediments: reproducibility and comparability of results. J. Paleolimnol.25: 101-110.

Heliotis, F., G. Vellidis, D. Bandacu \& C. Pringle, 1994. The Danube Delta: historical wetland drainage and potential for restoration. In Mitsch, W. J. (ed.), Global Wetlands: Old and New. Elsevier, Amsterdam: 759-767.

Ibelings, B., L. Török \& R. Dumitru, 2000. Plankton dynamics along a hydrological gradient in Danube Delta lakes. In Oosterberg, W., M. Staras, L. Bogdan, A. D. Buijse, A. Constantinescu, H. Coops, J. Hanganu, B. W. Ibelings, G. A. M. Menting, I. Nãvodaru \& L. Török (eds), Ecological Gradients in the Danube Delta Lakes - Present State and Man-Induced Changes. RIZA Institute for Inland Water Management and Waste Water Treatment and DDNI Danube Delta Research Institute, RIZA Report 2000.015, Lelystad and Tulcea: 71-94.

Krammer, K. \& H. Lange-Bertalot, 1991. Bacillariophyceae 4. Teil: Achnanthaceae. In Ettl., H., G. Gärtner, J. Gerloff, H. Heynig \& D. Mollenhauer (eds), Süßwasserflora von Mitteleuropa, Band 2/4. Gustav Fischer Verlag, Heidelberg: 437 pp.

Krammer, K. \& H. Lange-Bertalot, 1999a. Bacillariophyceae 1. Teil: Naviculaceae. In Ettl, G., J. Gerloff, H. Heynig \& D. Mollenhauer (eds), Süßwasserflora von Mitteleuropa, Band 2/1. Gustav Fischer Verlag, Heidelberg: 876 pp.

Krammer, K. \& H. Lange-Bertalot, 1999b. Bacillariophyceae 2. Teil: Bacillariaceae, Epithemiaceae, Surirellaceae. In Ettl, G., J. Gerloff, H. Heynig \& D. Mollenhauer (eds), Süßwasserflora von Mitteleuropa, Band 2/2. Gustav Fischer Verlag, Heidelberg: 611 pp.

Krammer, K. \& H. Lange-Bertalot, 2000. Bacillariophyceae 3. Teil: Centrales, Fragilariaceae, Eunotiaceae. In Ettl, H., J. Gerloff, H. Heynig \& D. Mollenhauer (eds), Süßwasserflora von Mitteleuropa, Band 2/3. Gustav Fischer Verlag, Heidelberg: 599 pp.

Lotter, A. F., 1998. The recent eutrophication of Baldeggersee (Switzerland) as assessed by fossil diatom assemblages. The Holocene 8: 395-405. 
Michelutti, N., M. Hay, P. Marsh, L. Lesack \& J. P. Smol, 2001. Diatom changes in lake sediments from the Mackenzie Delta, N.W.T., Canada: Paleohydrological applications. Arctic, Antarctic, and Alpine Research 33: 1-12.

Moruzi, C., 1968. Dezvoltarea fitoplanctonului in zonele stuficole din Delta Dunării. Hidrobiologia 9: 83-110 (in Romanian).

Moruzi, C., G. Vasiliu \& M. Stroe-Iancu, 1960. Contribuţii la studiul sistematic al fitoplanctonului din Delta Dunării. Institutul Cercetare Piscicole, Studie şi Cercetan 2: 131-179 (in Romanian).

Munteanu, I. \& Gh. Curelariu, 1996. Soil Map, Romanian Danube Delta Biosphere Reserve, 1:100 000. Danube Delta Institute, Tulcea and Directorate General for Water Management and Public Works of the Netherlands, Lelystad.

Nãvodaru, I., A. D. Buijse \& M. Staras, 2002. Effects of hydrology and water quality on the fish community in Danube Delta lakes. Int. Rev. ges. Hydrobiol. 87: 329-348.

Oosterberg, W. \& L. Bogdan, 2000. Water quality. In Oosterberg, W., M. Staras, L. Bogdan, A. D. Buijse, A. Constantinescu, H. Coops, J. Hanganu, B. W. Ibelings, G. A. M. Menting, I. Nãvodaru \& L. Török (eds), Ecological Gradients in the Danube Delta Lakes - Present State and Man-Induced Changes. RIZA Institute for Inland Water Management and Waste Water Treatment and DDNI Danube Delta Research Institute, RIZA Report 2000.015, Lelystad and Tulcea: 51-70.

Oosterberg, W., M. Staras, L. Bogdan, A. D. Buijse, A. Constantinescu, H. Coops, J. Hanganu, B. W. Ibelings, G. A. M. Menting,
I. Nãvodaru \& L. Török, 2000. Ecological Gradients in the Danube Delta - Present State and Man-Induced Changes. RIZA Report Nr. 2000.015, RIZA the Netherlands, DDNI Romaia and Danube Delta Biopshere Reserve Authority: 166 pp.

Pfannenstiel, M., 1950. Die Quartärgeschichte des Donaudeltas. Bonner Geographische Abhandlungen 6: 1-85.

Schmidt, K. F., 2001. A true-blue vision for the Danube. Science 294: 1444-1447.

Stoermer, E. F. \& J. P. Smol, 1999. The Diatoms: Applications for the Environmental and Earth Sciences. Cambridge University Press, Cambridge: 469 pp.

Török, L., 1998. Diversity and dynamic of the phytoplankton in Lakes Nebunu and Fortuna (Danube Delta Biosphere Reserve, Romania) in 1996. Analele Ştiinţifice ale Institutului Naţional de Cercetare şi Proiectare Delta Dunării 6: 1-9.

Tudor, M. \& L. Török, 1999. Studii preliminare asupra planctonului în ostrovul cernovca dupa un an de la inundare - 1997. Analele Ştiinţifice ale Institutului Naţional de Cercetare - Dezvoltare Delta Dunării Tulcea 7: 418-424 (in Romanian).

Van Dam, H., A. Mertens \& J. Sinkeldam, 1994. A coded checklist and ecological indicator values of freshwater diatoms from the Netherlands. Neth. J. aquat. Ecol. 28: 117-133.

Winkels, H. J., S. B. Kroonenberg, M. Y. Lychagin, G. Marin, G. V. Rusakov \& N. S. Kasimov, 1998. Geochronology of priority pollutants in sedimentation zones of the Volga and Danube delta in comparison with the Rhine delta. Appl. Geochem. 13: 581591. 
Appendix 1. List of diatom species identified in short sediment cores from lakes in the Danube Delta. Common synonyms are in angle brackets

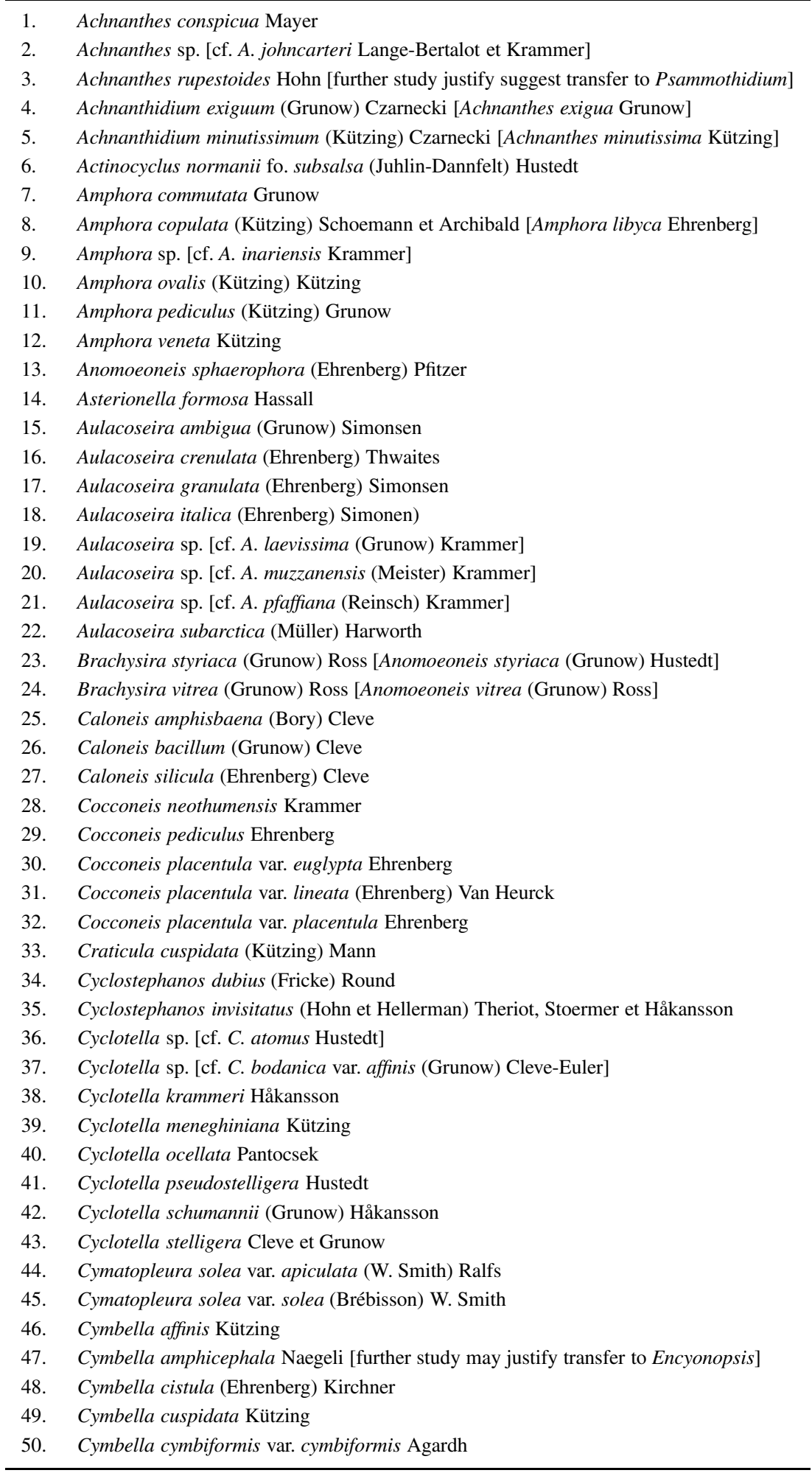


Appendix 1. Continued

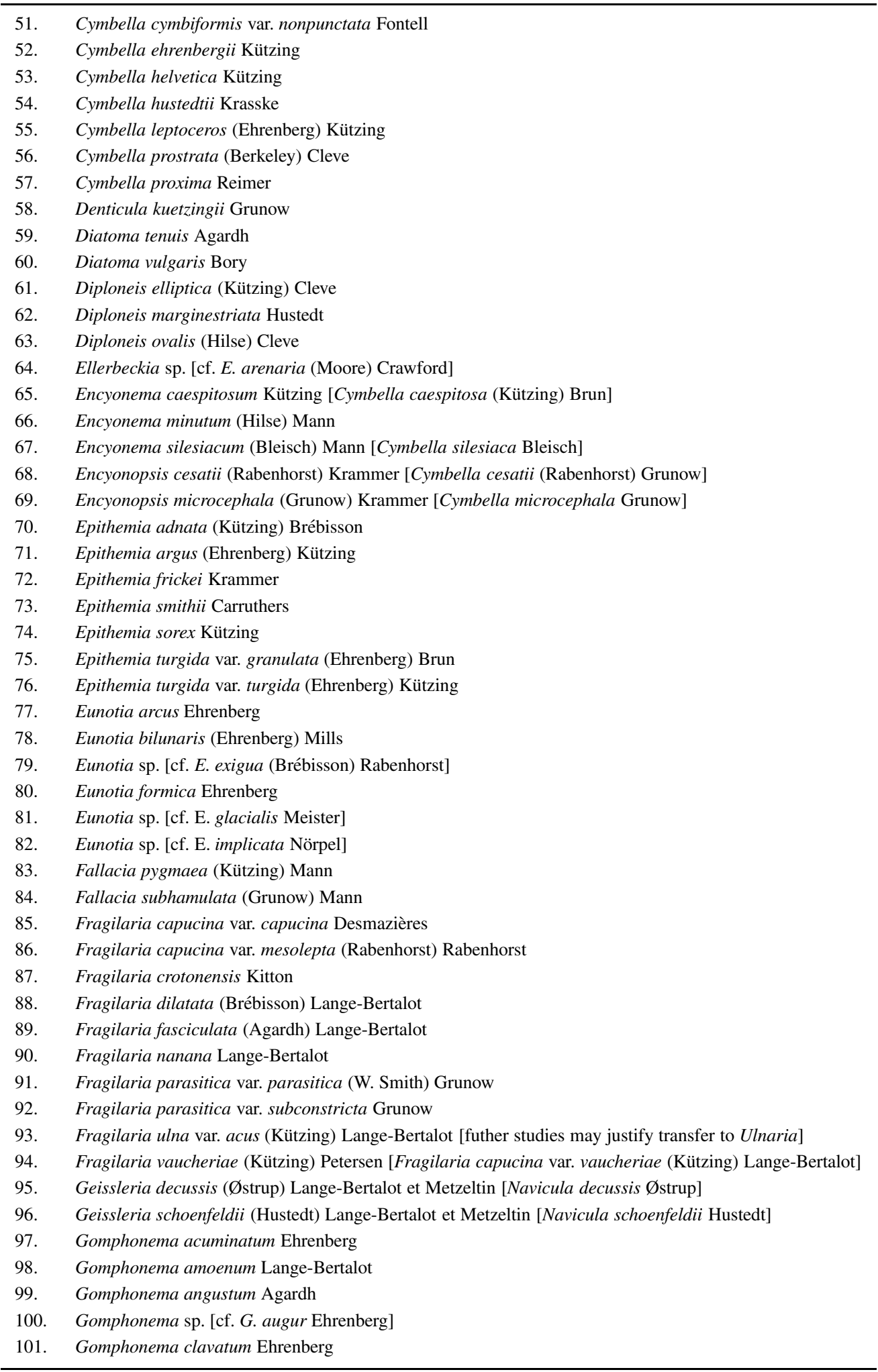


Appendix 1. Continued

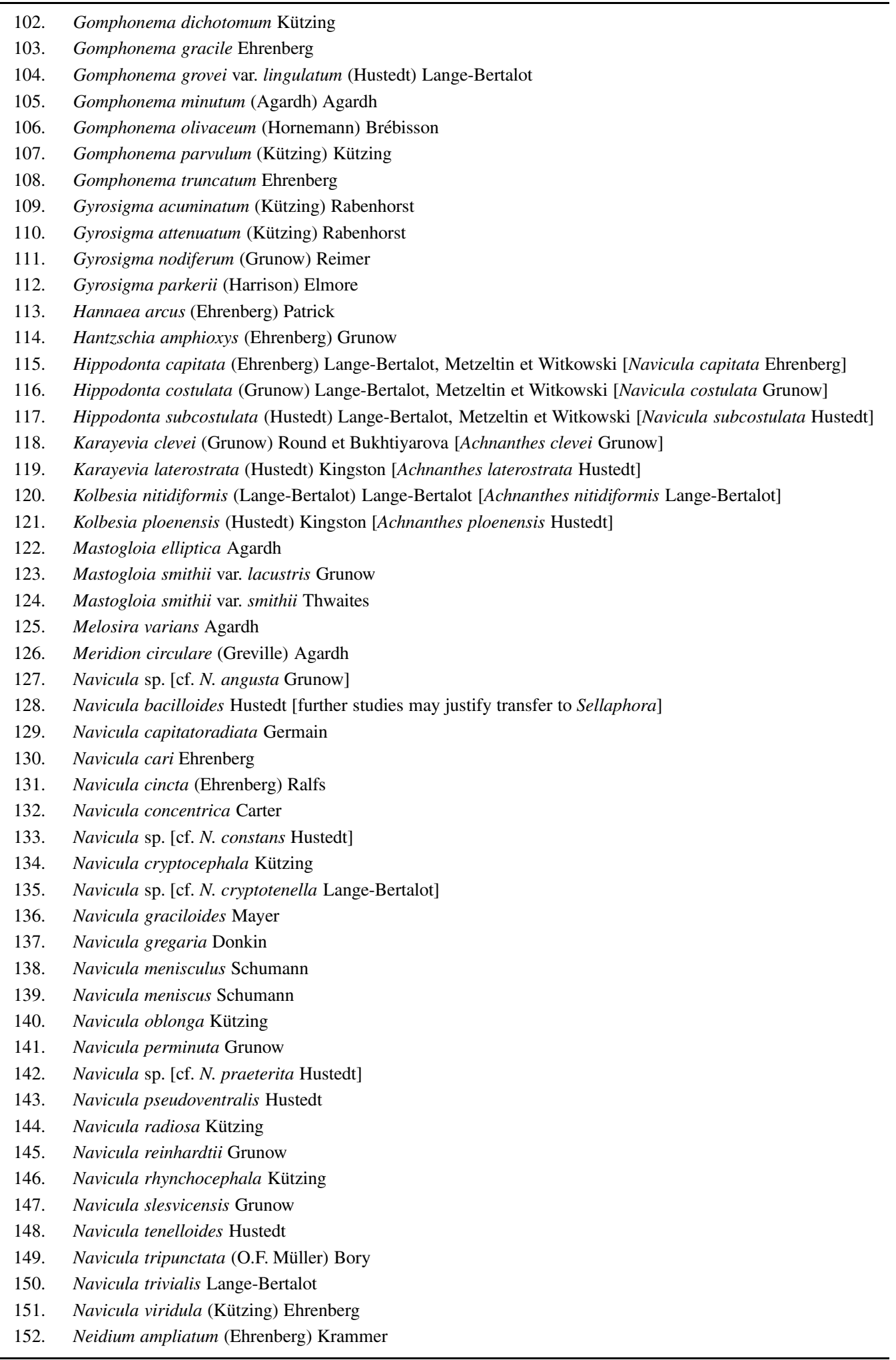


Appendix 1. Continued

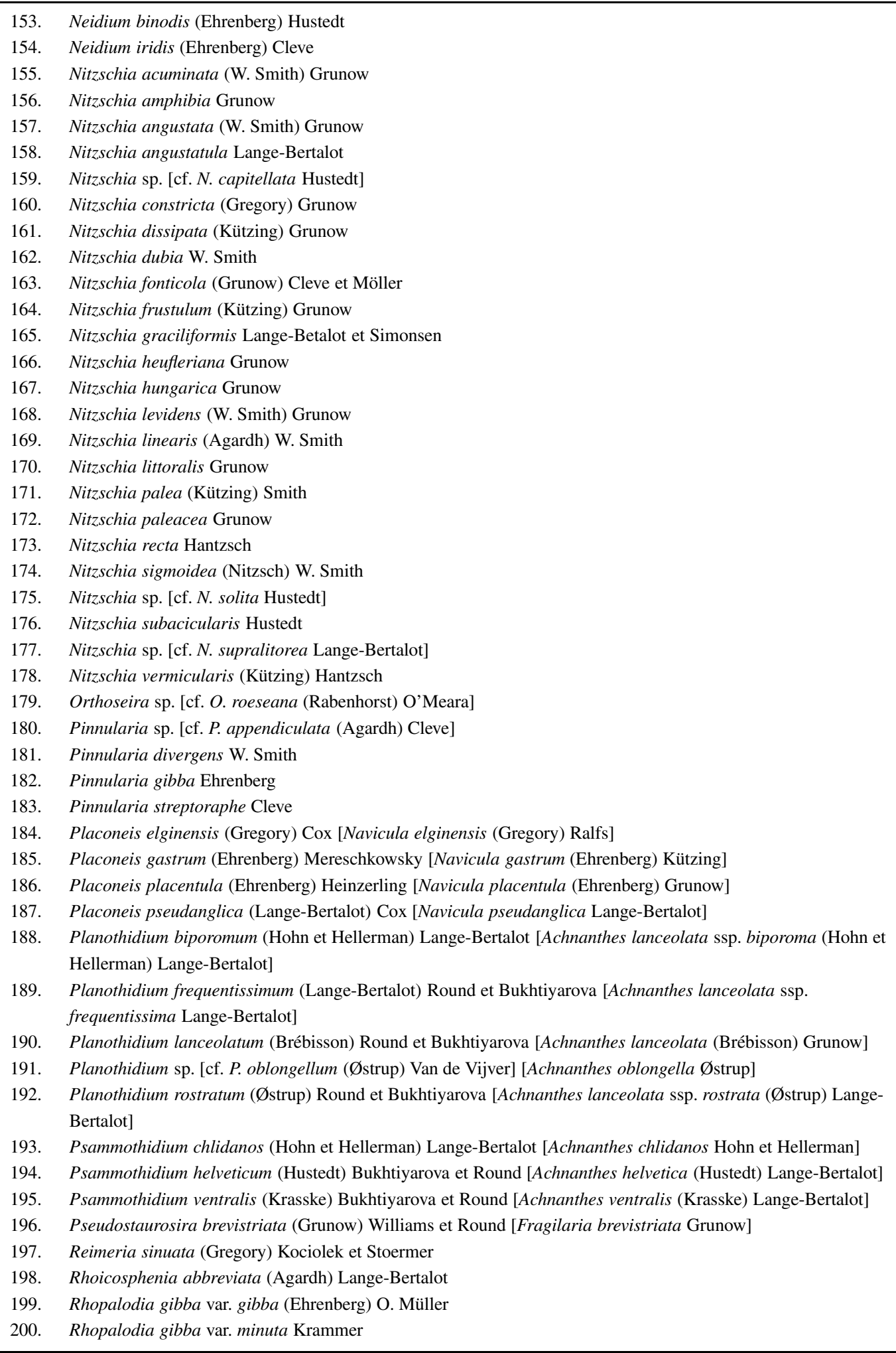


Appendix 1. Continued

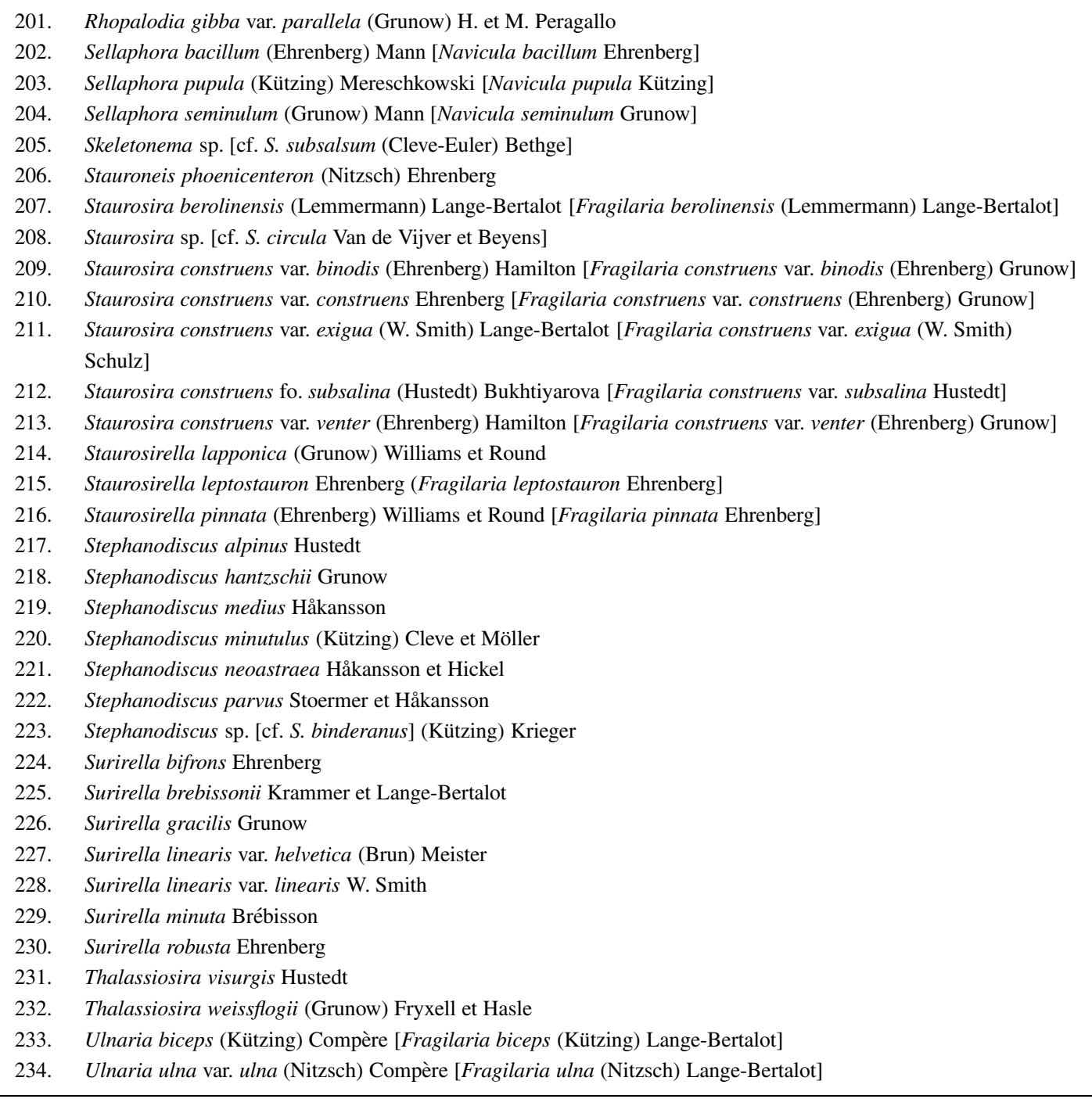

